\title{
Theme of the Revolution in the Artistic Discourse of Mikhail Prishvin
}

\author{
Alexander Modestovich Podoksenov* \\ Yelets State Bunin University, Yelets, Russian Federation; podoksenov2006@rambler.ru
}

\begin{abstract}
The aim of the paper is to analyze Prishvin's view of political, economic and social causes of the October Revolution, based on the material of the "The Worldly Cup" story, the writer's publicistic writing and diaries, previously unpublished due to the censure. Prishvin sharply criticizes the course of the Bolshevik Party for the destruction of all previous culture of the Russian people, being against of the Marxist ideology of class antagonism and primitive equality which is established by violence. It is shown in the paper that the class struggle implemented by the Bolsheviks in the village is destroying traditional morality and family ties upon which the peasant life is based. But although Prishvin considers the new government as a way of life of robbers and thieves, he is against the unilateralism in the assessments of events happening in the country. In contrast to the Whites and emigrants, the writer does not consider the failure of the Soviet idea as the failure of socialism in general. Prishvin has a keen sense of personal responsibility for the fate of the Russian people and state. Historical and philosophical analysis of Prishvin's creative heritage leads to the conclusion that the dialectical thinking of the writer allows him seeing not only the dark, but the bright side of life. Prishvin believes that there is a way out from the abyss of general enmity, where Russia fell after the revolutionary catastrophe, that the primitive psychology of hostility can be overcome only by means of Christian forgiveness and love. So Prishvin sees his self-affirmation and salvation himself as a writer in his devotion to good, not to evil of the class hatred.
\end{abstract}

Keywords: Bolshevism, Class Struggle, Creativity, Ideology, Marxism, Revolution, State

\section{Introduction}

"The Worldly Cup" written in 1922 is not only a work of art about the Great Russian Revolution, but also a historical document which is not fully evaluated, an eyewitness account telling us how the revolutionary red wheel rolled across the vastness of Russian Black Earth Region. First Prishvin planned to publish a story titled "The Monkey Slave" and he managed to publish few chapters of it in the newspapers, but the complete edition was banned personally by Trotsky. And only in 1979, the novel "The Worldly Cup" without the tenth chapter was published in the "Sever" magazine and for the final publication readers waited for another ten years. The immediate precursor of the story was the Prishvin's play "The Bazar" (initially titled "The Devil's Mortar") written by him in
1916-1920. As a demonic character of the revolutionary era, "The Devil's Mortar" expresses the spirit of "halfstarved acerbated philistine suburbs" ${ }^{1}$, representing those rebellious moods of the people who lugged away to the abyss the stagnant philistine life and age-old way of living in the Russian Black Earth Region province.

"The people I have described in "The Devil's Mortar" exist in reality and the Russian people familiar with the Russian way of life will know them"' , highlighted Prishvin the documentary and true-life basis for his play telling about the Yelets philistine mores in the spring of 1917 and therefore it is not by accident that he mentioned in the text a number of points of interest in his native small provincial town. The storyline of the imaginary being of Alpatov, the principal character in the story, is mainly the story of the writer's trials of life the who in the early

\footnotetext{
${ }^{*}$ Author for correspondence
} 
years after the revolution found himself in the Black Earth province, where he had to battle for the survival of his family. He worked a small estate inherited from his mother near Yelets where Prishvin, like other rural ploughmen, personally cultivated several acres of land. The estate was just like the other farmers' properties. It ended by requisition of all his property in the autumn of 1918 and his expulsion by virtue of the decision of the local village council. After the 'dekulakization', Prishvin works as a librarian in the Ryabinka village and as a geography teacher in his native Yelets gymnasium. After that, in the summer of 1920 he decided to go to Smolensk province to the homeland of his wife to work there near the small town of Dorogobuzh as a teacher in the Slednevo village and at the same time as an administrator of the Museum of the manor life in the former Baryshnikovs' estate. All these everyday details of Prishvin's life will become later the basis for his documentary story. The story by Prishvin about the October Revolution was so audacious for that time, that the editor of the "Red Virgin Soil" magazine A. Voronsky flatly refused to print it and frankly told the author that is was impossible to pull such a work through the censure. From the Writer's Diary of 1922 we know that, in spite of everything, Prishvin boldly and decisively sent "The Monkey Slave" for review to L. Trotsky who was back then, along with V. Lenin and G. Zinoviev, at the top of the Bolshevik Party hierarchy. In fact, the story sending date itself (August 24) is a documentary evidence of the spiritual condition and frame of mind of the author in that time, that helps understanding the peculiarity of the writer's philosophy, because, as written by Vygotsky in 1925, developing Plekhanov's ideas about the dominant role of psychology over ideology: "The psyche of social man is considered as a common substratum of all ideologies of the era, including art"3. M. Bakhtin also wrote about the importance of the intonational, emotional and value context for the understanding of the phenomena of art, emphasizing that the deep extra-textual layers of the impact on the author are like "a dialogic background of his perception. To a certain extent, the problem of social (nonverbal) dependence of a work is confined to it"4. In contemporary epistemology, an indisputable condition of cognitive process is that "not only the literal text and its objective meaning, but also the personality of the speaker or writer shall be subject to understanding $<\ldots>$ only by considering the genesis of thought we can properly understand them"s.

\section{Literature Review}

As we know, the whole social and cultural history of the Russian October Revolution of 1917 up to the beginning of the 1990s was under strong pressure of the political situation, which had a distorting effect on literature and literary criticism. In the late 1940s, Prishvin noted that "the politics has taken away from the Russian writers their moral prestige, so the writers have become just clerks", because every statesman "when seeing a horse art, thinks only about how to hitch it to the cart with his political burden"6.

This is confirmed by a characteristic opinion of connoisseurs of Prishvin that in "The Worldly Cup" the writer has not examined in details and has not completed a number of topics. So V.N. Chuvakov, being inspired by socialist realism and deciding to fix the "defects" of Prishvin's relationship to reality, writes: The autobiographical character of the story, Alpatov, understands better and better "on the subconscious level [emphasis mine - A.P.] the meaning of active, lifeaffirming humanism brought and maintained in a remote Russian village by the socialist revolution"7. But the reader has the right to expect that the purpose of criticism is to facilitate understanding of a literary text, not to engage in an ideological propaganda. One can hardly agree with the opinion of V.V. Agenosov that "Prishvin never accuses the revolution, the people and the intellectuals of things happened. Along with the character, he recognizes that people 'do not know what they do', that there is no specific enemy"s. Apparently, the researcher's conclusion has resulted from the opinion that in the novel "the writer's idea is painfully struggling among the different views on the way of life transformation" and "empirical unthought material creating the well-known philosophical indeterminacy and gibberish" can be explained by the fact that the flaws of "The Worldly Cup" are due to the author's lack of class consciousness and are derived from the "rationalism of a confused member of intelligentsia". However, it should be noted that the critical passion of 'Soviet' connoisseurs of Prishvin, of course, is not their personal 'fault' or professional shortcomings of the study. The realities of the life of society are such that in an era of political pressure on the art not only the author but also his critic is subject to censure. However, a fundamental methodological defect of the party and the class approach proper to socialist realism consists in the fact that the 
formal, inadequate and ontologically inappropriate for the analyzed phenomenon estimates were wrongly brought into the literary concept. As known, due to the censure obstacles "The Worldly Cup" novel fell into the category of "banned" literature and was published uncut only at the end of the 1980s. Being anachronistic, "The Worldly Cup" objectively remained without comments and analysis of its contemporaries, so a lot of displayed in the literary text historical details and circumstances, the meaning and significance of which was understood by the generation of the 1920s, require the researcher's assistance for readers who live in the $21^{\text {st }}$ century. And as the author defined the genre of "The Worldly Cup" as "a book in the form of a diary", it is clear that many articles and monographs consecrated to philosophical ideas of the story, without due regard to diary notes, are objectively deprived of the necessary context of Prishvin's creative laboratory sensitively responding to the social, philosophical, political and moral problems and trends of his times.

The special significance of the Diary for understanding the Prishvin's creativity consists not only in the fact that draft records and plans contained in it and entered later in the works of art reveal to us particularities of his creative method, but also in the fact that the text over which the censure has no power, reveals the true worldview relation of the writer towards the reality. The total volume of Diary entries of Prishvin related to the revolutionary period is much bigger than the text of "The Worldly Cup", that is why they are not, in a sense, a scaffold for the story about the revolution, but the very story is a scaffold for the diary as independent work of art, unique model of philosophical prose of the $20^{\text {th }}$ century. And since now, i.e. up to 2015 the publication of Prishvin's Diary is not yet completed, it is evident that it is too soon to draw conclusions of the scientific study of "The Worldly Cup".

\section{Methodology}

Methodological basis of this article has been determined by the specifics of the research subject that requires the use of the approaches that make it possible to accomplish purposes and tasks in the most productive way. The following methods can be distinguished: The biographical method, considering the personality of the writer as one of the determining factors of his work that makes it possible to trace the evolution of his writer views; dialectical method involving the analysis of the struggle and the combination of opposite principles that determine the formation of writer's philosophy; cultural-historical method used to analyze the dynamics and socio-cultural context of the development of Prishvin's view of the world; comparative-historical method allows exploring the creativity of Prishvin in the cultural and dialogue contexts by comparing his philosophical, ideological, artistic and literary discourses with concepts of philosophers and texts of other writers; the use of hermeneutical method is based on the fact that the scientific analysis of artistic and journalistic texts of Prishvin is impossible without his diary as a necessary context of the creative laboratory of the writer's thought, responsive to many social, philosophical, political and moral problems of his era.

\section{Results}

\subsection{Economic and Political Context of National Everyday Life in the Revolutionary Era}

"The Worldly Cup" is an eyewitness account of the Bolshevik regime disastrous for the Russian people and culture. The very image of the Bolsheviks is unpleasant for the artist to disgust: They are former criminals and revolutionary losers and deserters who had fled from the front. Principles of public administration inculcated by Bolshevism are also demonstrative: Class hatred and violence, theft and bribery, nepotism and deception. From the first pages of the story, from the conversation of men who have come to the 'contribution' as popularly called Taxes Collection Commission located in a former manor, it becomes clear for everybody that the newly appointed commissioner would be a comradely man, the same rogue as the old one. And although the old one has been dismissed, "he's gone into hiding in the post office, after some time when everybody forgets about him, he will reappear. He will have a thorough rest!"', complained the peasants about the lack of principles of the new government.

It is clear that the peasants are well aware of the simple homespun truth that the Bolsheviks condone 'their' villains, so they perceive the Soviet power as an alien to the common people and it is not a sin to deceive it.

It is not by accident that when contributing, almost everybody has "a stone as a weighting in each tow, a lot of 
sand in the flour, raw-boned sheep or ill chicken, only for the sake of appearance, because if no contribution made and you get caught, there will be no tolerance.

- Do you have it?

- Yes, I do! - answers a peasant promptly", being just perfectly aware that the commissioner hints at the homemade moonshine, called among the people liquid bread', which became since the revolution a bribe a lot more popular, than money. And the fact that in private life under socialism "even street cleaner's services are available only for vodka" was noted by Prishvin once again in $1943^{10}$. The fact that the homemade moonshine and vodka for centuries served in Russia as a universal and traditional exchange value was discussed and repeated by national litterateurs many times. But only Prishvin keenly noticed the pattern of decline in the authority of government specific for Russia when in troubled times the people start drinking homemade moonshine instead of vodka. At the very beginning of World War, Prishvin described in his "Delighted Russia" essay (1914) how joyfully the people welcomed the ban of officially produced vodka, which ended the society corrupting "history of taverns out of which all kinds of rioter and robbers riffraff including the last of the today's hooligans were walking out"11. At that period, already after two or three weeks, even completely hopeless and despairing sots and drunkards, shorn of their booze, began to look human, which was enthusiastically and idyllically noted by the writer: "A crowd of people is asking me in harsh terms to write to the Emperor a petition to ban the official vodka for the whole war period"11, who expressed patriotic willingness to compensate the loss of income by his personal donations.

However, very soon, instead of the use of official vodka people again began to produce the moonshine and this process with the growth of the state anarchy began to increase dramatically, "When the landowner is short of his own workers and cannot manage the hay cutting or harvesting and he needs to beg the peasants for help, so for a short time they become the masters and the landlord kind of loses his authority, then a behavior of a man represents the state of the government being under the thumb of various Soviets of Workers, Soldiers, Agricultural Laborers: Oh, how they put on airs and bully: We trust you so-so, etc.. If only they can have some vodka, but there is no vodka and authorities are powerless.

"If you give us some meths," say they, "we'll do it."

But the landowner has no meths. Neither does the government, it has no this meths-power"12, wrote Prishvin in the summer of 1917 about the incapability of authorities to influence people. So after the February Revolution simple peasants having become for a short time masters, under the deleterious influence of Bolshevik propaganda, began to destroy the old state, creating local administrations: The rural peasant councils and committees, whose primary purpose was the seizure and repartition of landowners' land. The atmosphere of binge drinking reigning in the village in many ways contributed to the rampancy of revolutionary anarchy and lawlessness: "August $7<\ldots>$ In Moreva they have used the whole rye to make moonshine and they even come to borrow some of it from use"12, said the writer in the Diary in 1917 regarding the causes of constant fights with shooting among men in the village next to his property.

In one of his essays Prishvin writes that by the middle of September, 1917, the moonshine was the most widespread, the cause of which was extremely depressed spiritual state of the peasants caused by the collapse of the hopes to get enough land in the course of the revolutionary redistribution and by a rampant inflation in the domain of all industrial goods. Still, the main reason of the fact that people took once again to the bottle, according to the writer, became the more and more increasing weakness of the economy and state policy. It turned out that the marketable grain spent for moonshine production and sold in the village, brought the benefit 8 times and in the city is was already 20 times bigger, while local militia recruited from the same village peasants was completely impotent against moonshiners. But it never occurred to the peasants woozy by moonshine that after having done justice upon landlords and having destroyed the old monarchy, they would be severely punished: Soon after that the Bolsheviks despoiled the peasantry of both the land and power. Meanwhile, in the summer of 1917 it seemed to many men in an alcoholic delirium that the landlord's estate is the paradise where they are called by revolutionaries. And deceived by the socialist dream about the universal equality, liberty, land and peace for all the peoples, the men went to rob, but of course, the master's land and goods were not enough for everybody, which caused the envy and even more anger towards both masters and their own a little more agile fellows, who managed to profit during the debacles in landlord estates.

The spiritual master as the rioters were the Bolsheviks, who in the name of world revolution began to push Russia to the death, promoting the idea of class struggle 
and kindling among the people a feeling of general hatred and anger: "It was just an hurricane whirled across our area, those speeches of people who called themselves Bolsheviks and was telling all sorts of nonsense, calling our peaceful peasants to capture, violence, immediate carve-up of the land, which meant to immediate mass murders among villages. Later the peasants came to their senses and yesterday at the gathering they decided the following:

"We have to beat them if they show their faces here again", wrote Prishvin in the summer of 1917 about the attitude of the local population towards the ${ }^{12}$.

But when the revolutionaries indeed seized the state power, it was too late to beat them. Then, the Bolsheviks already have started to treat people like conquers treat the conquered population. And in "The Worldly Cup" men murmur helplessly against their foemen:

“- The contribution's pissing me off!

- Damn it!

- And we must contribute everything: Our money, bread, horses, cows, pigs and chickens as well.

- Yes, chicken as well!".

Some explanation should be given to this scene from the story that clearly describes the practical application of the ideology of Bolshevism in form of general collectivization of all properties of peasants. If in the early days after the revolution, one of the main sources of the budget replenishment of Soviet power, especially at the local level, was the contribution that extended up to the requisition of all the food, the 'collectivization of chicken' has become one of the main measures in order to implement the directive of the VII Congress of the RCP (b) [Russian Communist Party (of Bolsheviks) - A.P.] requiring the "forced unification of the entire population in consumer-productive communes"13. The ideological justification for this was given by Lenin, who at the height of the famine in the spring of 1919 at a meeting with delegates of the Congress of agricultural workers made a statement in support of the "Regulations" of the VTsIK [All-Russian Central Executive Committee A.P.] prohibiting for laboring men to have private farms, chickens and gardens: "If we again start having individual gardens, individual animals, birds, etc., then, perhaps, everything will return to the small farms just like it has been until now. In this case, is there any use in making unnecessary fuss? Is it any use in instituting the Soviet economy?"14

\subsection{Images of the Violent Nature of Power}

Therefore, it is no coincidence that the theme of power, this never dozing demon of violence, is one of the key themes in the novel, because in the Soviet regime politics Prishvin finds the same methods of violence against the people as in tsarist times, only the motive is different: "The old state power was the work of the beast in the name of God, the new government is the work of the same beast in the name of Man"2. In "The Worldly Cup" this lurking proximity between monarchy and Bolshevism is disclosed by the writer by means of a folk parable that a fortune teller tells to Lenin who supposedly came to her to find out how the revolutionary turmoil would turn out: "Marfusha's got hammer and sickle". Lenin was delighted. "Do not rejoice, my friend, - said Marfa - come home, write words and read them from the other end" <...> "Hammer and sickle" - read now how it will end. [When reading in Russian it will be: Throne]

- Throne.

- That's how it will turn out.

- So, will it be a king?

- Not necessarily.

Maybe a president of $\langle\ldots\rangle$ do you think the president has no throne? The president's throne is maybe even worse than the one of the king"'. In such a way the writer reveals the main contradiction of Russian socialism: Having proclaimed the idea of serving the people and building a just society, the party of Lenin not only usurps the throne of the state, but also makes a revolutionary violence as a method of solving all social problems. However, the proletarian power presses the peasants not only by external violence, but it seeks to sow the seeds of strife also in the soul of the people. "The real punishment: Sergei Afanasiev laid a contribution amounting to five thousand to his father Afanasii Kutsupyi, "God damn you!" said Kutsupyi.

- Did he curse his son?

- Yes, he did, forever and ever"', transmit the peasants to each other the news of the approaching apocalyptic time announced by Gospel when the son turns against his father. So, Prishvin by applying evangelical phraseology and highlighting contemporary events through the context of biblical morality shows how the idea of class struggle, being introduced by the Bolsheviks in the village, is destroying the traditional patriarchal family ties, upon which the peasant life has been based: The son revolts against his father and the brother is against his brother. 
In "The Worldly Cup" the ideology of revolutionary violence is represented by Persyuk, one of the worst Soviet commissars, who suddenly rammed against a museum, either to investigate the denunciation about seditious statements of an old woman Pavliniha against the Soviet power or to search for free booze: "Who is here against us? $<\ldots>$ Here he is, the enraged ruler looking like Peter the Great at the execution of the shooters".

However, under the influence of peaceful words of rare object keeper, Persyuk has calmed down and starts talking to Alpatov about the most pleasant theme for him: Darwin's theory, joyfully waiting to hear once again from the connoisseur of antiquities a confirmation of the fact that humans really come from monkey. When Persyuk has warmed the soul with Alpatov's mention, although ironic, that a glass of alcohol is the easiest way to come back from man to monkey, the commissar has "suddenly stopped as if listening to himself and remembered:

- Yes, I remember, on the sea, it was nice to hide sometimes from the officer between ropes, drink a bottle at once, and then go to read Marx.

- Marx?

- Thinking at that time how to achieve...

- What to achieve?"

But the commissar could not remember anything from the scientific theory of communism, because at the mention of the holy name of Marx worshiped by each revolutionary, the soul of Persyuk became again extremely an hungered: "Stop! - He threw back his head and tapped on his throat with his finger. - Do you have?

- Only some meths in the lamps.

- Give me the lamp.

- Don't get poisoned: It's a copper lamp.

- Bring it!".

However, the commissar could not catch up the idea even after the three year old poisonous green meths from all copper museum lamps poured into his throat. The Prishvin's Diary allows more deep understanding of the ideological and political meaning given by the author to the artistic image of Persyuk. It is mentioned in the Diary that the prototype of the commissar Persyuk was a former sailor Simon Kondratievich Lukin, one of the leaders of Yelets Bolshevik organization, who loved to tell how, during the naval service, hiding in the marine rope ring, he "was reading Marx's "Capital" and according to his faith in Marx a blessed life for the whole world was revealed to him. Downward thoughts of a literate Jewish about the economic necessity were transformed by a young Russian sailor into the absolute freedom for the individual" ${ }^{15}$. After the revolution, Lukin was appointed to a commissarship and from a simple sailor he turned into a severe power, which rejected both the individuality and all kinds of freedom and at every opportunity harshly called to beat the enemies of the proletariat. So the revolutionary power in the reality, notes Prishvin, becomes divided into many Persyuks through which the Bolshevism is parodied and carried to an absurdity in the novel, causing doubts about the validity of the whole Soviet state.

It is clear for Prishvin that the socialist idea, as interpreted by the Russian revolutionaries, is totally inhumane, because it requires a huge sacrifice. This contempt of the Bolsheviks for the countless victims of the triumph of their ideas, when greatness is measured by the number of sacrifices made for it is represented by the writer in a phantasmagoric scene of the funeral of the lead character of "The Worldly Cup" - Alpatov, one chapter of which is called: "Mystery". It seems to freezing Alpatov that his body, mistaken for a dead Bolshevik, is carried "in the red coffin back to the city to the Revolution Square, where Karl Marx is"'. Here, a former deacon Yegor Ivanovich performs the rite of 'red funeral' near honorary graves of commissars killed at the combat post brightly teaching the old ladies that the real Gospel of Bolshevism is entirely in Karl Marx. And who else, if not the former deacon can give an authoritative opinion about the religion of Marxism.

And the writer stresses the significance of his statement by describing the former churchman (defrocked for drunkenness) as the leader of the world revolution: Yegor Ivanovich with a characteristic Lenin gesture "put his hands in his pockets $<\ldots>$ and without taking them out, walked back and forth near the coffin, thinking and suddenly took out one arm, reaching it forth towards the dead man:

- Comrade". 9

Chuckles from the crowd of gawkers came to see the "red funeral" scene, astonished by the mysticism of his address to the decedent like he was a living person, were interrupted by no less fantastic phenomenon: Suddenly a snow dust whirlwind threw out at the square a car from which "a young man shouted out with a cold voice:

- Death!

Everybody fell silent in fear.

- For one head of this comrade, we'll take a thousand heads: Death, death!"'.

In desperation, alarmed by the thought that thousands 
of innocent people would be killed now because of him, Alpatov started screaming and then woke up in a cold sweat. In order to understand the meaning of what happened, it is necessary to refer to the Prishvin's publicistic writings and Diary entries of 1917. This mystical scene was created by the artist based on his recollection of the funeral of the victims of the revolution seen by him in 1917 in Petrograd on the Field of Mars, when the Bolsheviks, having copied from the French Revolution the style of wrapping the killed men in red cloth, established the custom of burying their fallen comrades in red coffins, singing the Marseillaise.

"I felt that the red would not get over just like that, sooner or later the red coffins would rise up and when seeing them both the actors and the audience would go crazy - prophetically Prishvin noted in an article in 1917. - The actors have forgotten that they are only actors playing a man created by the French Revolution. They have forgotten and suddenly the French play has turned into a Russian mystery about the origin of humans from monkeys, a terrible mystery unseen by the world where monkeys were sitting on thrones and the souls of the dead were swirling on the black streets in red coffins" ${ }^{\prime \prime}$.

The writer took from real life also the threats of the Bolsheviks to execute hostages for every dead revolutionary. In the Diary dated 1918, Prishvin talks about spontaneous riots that erupted in Yelets county, when the peasants refused from Bolshevik mobilization in order to be sent to fight with the approaching Germans. Punitive detachment of Red Guards decided then to make a long "Eremeev night" for the rebels and people started being shot and executed everywhere: In such a way the local people renamed Yelets massacre, having a dim recollection of the name of the "Massacre of St. Bartholomew", but well understanding the essence of the old history of the massacre of the Huguenots by Catholics in 1572 in Paris. Being an eyewitness of the events, the writer tells: When people from nearby settlements, protecting their property and lives, "picked up courage and hacked three Red Guards to death with axes", the punishers began cannonading settlements. Then, following all the Soviet rites just like in Petrograd on the Field of Mars, the Bolsheviks buried three dead punishers in the Haymarket Square of Yelets and the city "dictator accompanied by a funeral gun salute made a speech and swore on the grave that for each head of dead comrades, he would get a hundred bourgeois heads"15. The Prishvin's recollection about a conversation with a member of the
Soviet government bears evidence of the readiness of the Bolsheviks to sacrifice the whole enormous Russia in the name of world revolution: "I remember, in the 1919 I complained to Semashko about disgrace of shooting in Yelets and he reproached me with philistinism and said: "Try to understand that what is happening is a matter of great concern..." ${ }^{17}$.

This contempt for the ordinary people as for "the manure of history" came from the very top of Bolshevism. There is a remarkable record in Prishvin's Diary about the arrival in Yelets on October 30, 1919 of the leader of the Bolshevik socialism, Chairman of the CEC [Central Executive Committee - A.P.] M. Kalinin, who after his speech at the meeting of Yelets proletarians, in a private conversation with the writer, frankly stated: "People <...> is a cattle that must be kept in a stall, it's all kinds of bastard, with the help of which we can do something good for the man. When the man gets strong, then we will relent and will open stalls for all cattle. But meanwhile we'll keep it in closure" 15 . Hence, we can understand better the policy of the Bolsheviks against the population described in "The Worldly Cup" when commissars descend to collecting a contribution by means of torture. If the torture did not help to get a tribute, then power had another penalty for the most obstinate peasants. "Cold barn is now abandoned, a stencil-plate is in use: They burn on the foreheads the letters N.C. (No Contribution made)," tells Prishvin about the practice of collecting taxes by Yelets Bolsheviks in February 1919 and quotes the words of a local security officer: "It can't be helped, they are just this kind of folks $<\ldots>$ look directly at the man, who is he? And you will put him in the cold prison cell" ${ }^{15}$.

Exactly this justification was given by Persyuk in the story. When parrying the reproach that he not only froze men in the cold barn, but immersed them into the icehole he said: "...try to collect the tax and you will certainly practice immersion"9. Therefore, a defaulter man in vain complained to the commissar:

- "I have nothing!" - "Go to the ice-hole!" And he got dipped.

- He got baptized!

- Yes, they baptized him and asked: "Do you have anything?" - "Nope". They dipped him in the Name of the Father as well as in the Name of the Son. "Anything?" "Nope". And after going out from the Jordan for the third time: "Do you have anything?" - "Yes, I do".

- The man has been baptized.

- Russia is baptized on the rivers of Babylon. 
- On the Tigris and Euphrates.

- And Persyuk is the only baptizer..."'.

Direct historical evidences that refute all attempts of the Bolshevik propaganda to write off the violations of the law, cases of torture and cruelty towards the public to several "careless" commissars, representatives of local authorities, are policy documents and official decisions of the government.

It is known that Lenin himself being the leader of the Bolshevik Party and the head of the Soviet state, already six months after the assumption of power announced that the peasants are hostile petty-bourgeois class and proclaimed that "the laboring men should go on Crusade against the village hiding the bread $\langle\ldots\rangle$ the bourgeoisie and the small proprietors are against us, they do not believe in the new order"18. Therefore, all the "bread owners having surpluses of grain and not bringing them to the stations and place of acceptance shall be declared enemies of the people"19. And armed food groups of workers called by Lenin went to the "crusade" against the village, not only inspired by the idea of class fight against the peasantry and also by the Decree of the Soviet government, in accordance to which the requisitioners should be rewarded for the successful requisition of bread from the peasants. It was stated in the Decree of VTsIK and SNK [Council of People's Commissars - A.P.] "About the Extraordinary Powers of People's Commissars of Food", approved on May 13, 1918, which authorized the food groups to use the armed force and made provisions for the rewarding of informers for disclosure of the fact that the "enemies of the people" still had some bread. The reward was a half of the cost of the seized bread given in monetary form ${ }^{20}$.

Prishvin, who was a peasant at this time in the small Khrushchevo estate inherited from the mother near Yelets, wrote in his diary on May 26, 1918 how the said Decree was accepted in the village. "We are counting on the fingers all our primitive people who will follow Lenin and will lay information against those who are hiding their reserves. Zahar Kapitonov is a robber $<\ldots>$ Pavel Bulanov $\langle\ldots\rangle$ is a drunkard $<\ldots$. In the whole village we have about eight people, all of them are having criminal history, they are all criminals" 15 , says the writer of the moral reputation and social situation of the villagers, who actively supported the Bolsheviks in the early years of activity of food detachments and Committees of Poor Peasants.

\subsection{War Communism Policy in the Village}

The War Communism introduced by Lenin's Party as well as the expropriation of all product surpluses undermined any interest in increasing labor productivity and growth of agricultural production. The way out of the growing devastation of the country's economy sector was seen by the authorities not in the development of production, but in the further strengthening of the class struggle, the imperative of which was lying in the following principle: "Take away and divide".

In response to such a policy, the peasantry, of course, was reducing planting and sometimes was using sawedoff guns, so in order to suppress rebellions opened everywhere, the power was sending regular Red Army units armed not only with machine guns, but with cannons as well.

In fact, there was a real peasant war against Bolshevism in villages, which, in particular, is described in "The Worldly Cup": Peasants are telling that the bandit baron whose name is Kysh (it means the fear that disperses the reds) in his area "has an island with bogs eighty miles around and there are various pits where men are bringing food"16. And one of the Prishvin's Diary entries of 1919 is telling that that Red Army troops sometimes were running away from villages without a fight: "September 24. <...> There is a peasant rebellion opened in Izvoli: A requisition group has been kicked away. The people say that the 'liquidation has been peaceful, without a single victim,' i.e. they have simply fled"15.

That is why the commissar Persyuk behaves heinously being angry about this attitude of peasants and beats in tortures so-called "surpluses" out of peasants. Baptizer of defaulters in the ice-hole and the revolutionary contribution collector Persyuk is miffed even at Savin, the representative of the "soft-bodied" intellectuals who are not able to understand the essence of revolutionary expediency. The Bolshevik power vicegerent in the village, he is frankly perplexed: Indeed, he is faithfully following the Order of Lenin, the head of the Soviet state and the leader of the world revolution, who has issued a directive for all the local authorities "to effect the will of the proletariat, using its decrees and in the case of absence of the corresponding decree or incompleteness of it, to be guided by socialist sense of justice"14.

In reality, this 'socialist sense of justice' of the Bolshevik commissars often turned into a revolutionary lawlessness, followed by Persyuk as well, who in torture 
beat extraordinary taxes and food surpluses out of peasants declared by a special Decree of the proletarian state as wealthy men and 'enemies of the people'. It is notable that it was at the suggestion of Lenin that Soviet of People's Commissars legislatively determined a property qualification or dividing line between richness and poverty, resolving that "rich men are those whose amount of grain (including new crop) is twice and more than twice as big as the amount needed for selfconsumption" 21 . It is necessary to emphasize that the fact that entailed significant legal, political and moral consequences was that the consumption rate itself was given only in the annotation to the "Decree of VTsIK and SNK about imposition of a natural tax in the form of contributions of the agricultural products on farmers" dated 30 October, 1918 with a note not to mention in the press: "To increase the rate of consumption up to 16 pounds without mentioning about it in the decree and the introduction" ${ }^{21}$. It should be noted that 16 pounds, i.e. $256 \mathrm{~kg}$ per 1 person per year was 700 grams of bread per day, with vital necessity for peasants to feed the cattle and poultry.

It is well known that the Bolshevik power ideologically inspired and politically justified the violent excessive acts of "socialist sense of justice" of commissars and members of food appropriation groups towards the peasants. In the years of "war communism" their daily allowance was not peasant's 700 grams, but varied from 100 to $200 \mathrm{~g}$ of bread per day depending on the situation in the country. However, the peasants were not even aware of existence of a limit of revolutionary energy of food detachments in the process of "surplus" withdraw. Indeed, the decision of Soviet of People's Commissars regarding the 700-gram daily consumption rate for farmers was recorded only in the annotation to the Decree with the note "not to mention in the press" because it was only for propaganda purposes for internal use at the upper levels of the ruling party, while local authorities were invited to follow interests of the proletariat and the "socialist sense of justice".

By the way, the daily allowance of the rural school teacher was equivalent to 200-gram (half-pound) daily norm of laboring man, as evidenced by an entry in the Prishvin's Diary: "I have gone to Ozerische (county) 12 miles from Alexin to receive my $1^{\text {st }}$ category monthly teacher allowance - 15 pounds of flour, I've covered five miles, spent two hours in the Executive Committee arguing, quarreling (No allowances for steaches [school teacher - A.P.] yet! - How should families of steaches live now? and so on). I've returned home late at night in the moonlight $\langle\ldots\rangle$ have found 16 onions scattered on the road and, of course, I have picked them up and eaten two with bread"2. Indeed, it was not always possible to obtain this cherished allowance: "A teacher from Elenkin has come $<\ldots>$ she's said she had been given three pounds of flour for three months and the school was not been in the winter, because there were not enough woods!" 2 These facts from the miserable life of rural teachers after the revolution recorder by the writer largely explain contemplations of inhabitants of the former manor, when just before the winter a new steache (Alpatov) came to them: "...how will he live here in a cold house, having no pig, no potatoes, being naked, without shoes and with barefooted kids?"

Episode in "The Worldly Cup" telling about a spontaneous meeting of hungry women in the town square during a mystical scene pseudo-funeral of Alpatov is the same evidence of the fact that the new government could not provide a normal food supply for townspeople. "Clear the area!" shouts intensely a policeman. "It's a funeral, not a rally, come on, clear the way!

And he stabbed his sabre at a woman, only at one, but a hundred women jumped out.

- We haven't received even eighth of a pound today. You're saying "Freedom, freedom" but not giving any bread to us, why on earth de we have to need your freedom?

- Go to work!

- Give me a place to work!

- Take it; you are the one who is not going there.

- You're lying!"9.

Shouts and screams of town inhabitants are used by the author in order to describe the mood of the hungry people living in the realities of economic devastation, when the Bolsheviks having seized state power were not able to provide people with either work or 50 gram starvation rations even those who had a right to this government dole. Thus if registered in house committees, nonworking city inhabitants who did not have any property received from local authorities an allowance of $1 / 8$ pound (50 grams) of bread, as told in the Prishvin's essay dated February 17, 1918: "As recently as a couple of months ago we pretty complacently talked in Petrograd about the lack of food. $<\ldots>$ Now, when we've turned out to have an eighth of a pound of bread", many have been 
confused by the sudden "emergence of famine fever"22. So many episodes of "The Worldly Cup" not only tell us about the real facts and events of the life of the writer and society, but also give an idea of the spiritual atmosphere of the revolutionary era.

\section{Discussion}

Prishvin gives the most negative assessment of the revolution, considering the new reigned government as a public way of living of robbers and thieves and it confirms his understanding of one of the main laws of history: All revolutions begin with saints and end with bandits. But he is against the one-sidedness in the assessment of the Civil War: "Our commissar hooligans are only a reflection of the white tsarist noble hooligans, they are in equilibrium, but there is a positive sign on the side of the Reds - retribution. $<\ldots>$ It is necessary to remember that such bastards are now on the side of the counter-revolution, that if they win, we gonna weep for the Bolsheviks. So the truth has been divided in half and there is a lie everywhere: We seed a lie and we live in a lie"2. It is interesting to consider the Prishvin's opinion about a paradoxical similarity of spiritual inferiority of the warring parties, whether in the capital or in the provinces. "It is the intelligentsia that is to be blamed for the existence of the Soviet regime, without it this power could not exist, you should to run to us and if you do not leave, we will spifflicate you later", quotes the writer the threats of the Whites being near Yelets. "In brief, the question is this: Trotsky or Purishkevich, "kill bourgeois' or 'kill the Jews'. Bolshevism is the confession of the Third International, the Black Hundreds is the confession of nationalists, they both (Gorshkov and Mamontov) have confessed in Yelets enough for us to be able to refuse from both of them"15.

But in spite of all the crimes and mistakes of government, unlike the Whites and immigrants, the writer does not consider that the failure of the Soviet idea is the failure of socialist ideas in general. Prishvin has a keen sense of personal responsibility for the fate of the Russian people and state, "I am not turning against the current power because my sense of copartnership with it prevents me from doing this. My participation in the creation of the Monster was, of course, the smallest one, unconscious and it has probably consisted in connivance, mindlessness and so on. But still..., he writes to Ivanov-Razumnik, promising to find more powerful arguments in defense of socialism in the next letter ${ }^{2}$. The idea of emigration is also unacceptable to him because of personal involvement in what is happening in Russia: "This is all ours and the Bolsheviks with the Commune are ours as well. $<\ldots>$ It's all our disease, there is nothing kept secret that will not come to light", he wrote in 1919 in the midst of the civil war; ${ }^{15}$ and the same was repeated in 1920: "It is our, our government! We are all guilty of it..."2. As a representative of the part of the Russian intelligentsia, which in its time was be enthusiastic about ideas of European socialism, the writer sees his own guilt for the accomplished coup d'état, "It were us who were 'communists', our selfish anger created demons. $<\ldots>$ The Communists are the image and likeness of our own past ordinary spirit" ${ }^{\prime 1}$.

\section{Conclusion}

In summary, it should be noted that the writer's dialectical thinking allows him to see not only the dark, but the bright side of life. Prishvin is convinced that we can find a way out from the abyss of universal enmity, where Russia has plunged after the revolutionary catastrophe, as the soul of the Russian people is naturally gentle: "I am saving by the ability of my soul to the expansion: Everything begins suddenly expanded and I love everything and I do not remember my enemies", said Prishvin in his Diary in $1920^{2}$. The lead character of "The Worldly Cup", Alpatov, has the same quality. He understands that the primitive psychology of hostility towards offenders can be defeated only by means of forgiveness and love. But the forgiveness does not mean for the writer the loss of ideological supports of personality. Prishvin himself never makes a compromise with evil and he is far from a passive contemplation of disaster and suffering of the people. The writer believes that his main task is to elaborate the only possible in conditions of a revolutionary society catastrophe strong position on life. That is why Prishvin creates "The Worldly Cup" which the modern reader considers not only as an eyewitness testimony of the revolutionary events, but also as an important historical lesson, giving birth to the analogy with the new Russian socio-economic era and the new time of troubles, which came again at the end of the longsuffering twentieth century. 


\section{References}

1. Prishvin MM. Bazar (Pesa dlya chteniya vsluh) [Bazar (Play for recitation)]. In Prishvin MM Tsvet i Krest [Color and Cross]. Saint Petersburg: Rostok. 2004. p. 339-57 [in Russian].

2. Prishvin MM. Dnevniki [Diaries. 1920-1922]. Moscow: Moskovskii Rabochii. 1995; 334 [in Russian].

3. Vygotsky LS. Psikhologiya iskusstva [Psychology of Art]. Moscow: Iskusstvo. 1968; 576 [in Russian].

4. Bakhtin MM. Estetika slovesnogo tvorchestva [Written Word Aesthetics]. Moscow: Iskusstvo. 1979; 424 [in Russian].

5. Gadamer HG. Istina i metod. Osnovy filosofskoy germenevtiki [Truth and Method. Fundamentals of philosophical hermeneutics]. Moscow: Progress. 1988; 704 [in Russian].

6. Prishvin MM. Dnevniki [Diaries. 1948-1949]. Moscow: Novii Khronograf. 2014; 824 [in Russian].

7. Chuvakov VN. Kommentarii [Comments]. Prishvin MM collected works in 8 volumes. Moscow: Khudozhestvennaya literatura. 1982; 2: 638-78 [in Russian].

8. Agenosov VV. Tvorchestvo M. Prishvina i sovetskiy filosofskiy roman. Posobie po spetskursu [Prishvin's creative work of and Soviet philosophical novel. Manual for a specialized course of study]. Moscow: Prometei. 1988; 127 [in Russian].

9. Prishvin MM. Mirskaya chasha [The Worldly Cup]. Moscow: Zhizn i mysl. 2001; 73-145 [in Russian].

10. Prishvin MM. Dnevniki [Diaries. 1942-1943]. Moscow: ROSSPEN. 2012; 813 [in Russian].

11. Prishvin MM. Obradovannaya Rossiya ("Russkie vedomosti”, 1914, № 187, 15 avgusta) [Delighted Russia (Russkie Vedomosti. 1914. No. 187. August 15)]. Prishvin MM Tsvet i Krest [Color and Cross]. Saint Petersburg: Rostok. 2004; 461-2 [in Russian].

12. Prishvin MM.Dnevniki. [Diaries. 1914-1917.] - Moscow: Moskovskii Rabochii. 1991. p. 432 . [in Russian].

13. Lenin VI. Sedmoy ekstrennyy sezd RKP (b) 6-8 marta 1918 $\mathrm{g}$ [Extraordinary 7th Congress of the RCP(b) 6-8 March 1918]. Collected works in 55 volumes. Moscow: Politizdat. 1962c; 36:1-76 [in Russian].
14. Lenin VI. Zasedanie I sezda selskohozyaystvennyh rabochih Petrogradskoy gubernii 13 marta 1919 g [Session of the first congress of farm laborers of Petrograd Gubernia. March 13, 1919]. Collected works in 55 volumes. Moscow: Politizdat. 1963a; 38: 22-30 [in Russian].

15. Prishvin MM. Dnevniki [Diaries. 1918-1919]. Moscow: Moskovskii Rabochii. 1994. 383 [in Russian].

16. Prishvin MM. Krasnyy grob. Slovo o tom, kak pokazala Rossiya, chto chelovek deystvitelno proiskhodit ot obezyany ("Volya naroda", 1917, No.164, 5 noyabrya). [The Red Coffin. A word about how Russia has shown that the human really descended from monkey (Volya Naroda. 1917. No. 164. November 5)]. In Prishvin MM Tsvet i Krest [Color and Cross]. Saint Petersburg: Rostok. 2004; 108-9 [in Russian].

17. Prishvin MM. Dnevniki. [Diaries. 1938-1939.] Saint Petersburg: Rostok. 2010. p. 608 [in Russian].

18. Lenin VI. Rech na II Vserossiyskom sezde komissarov truda 22 maya $1918 \mathrm{~g}$ [Speech at the 2d All-Russian Congress of the labor commissars May 22, 1918]. Collected works in 55 volumes. - Moscow: Politizdat. 1962a; 36:365-70 [in Russian].

19. Lenin VI. Osnovnye polozheniya dekreta o prodovolstvennoy diktature [The main provisions of the Decree on the Food Dictatorship]. Collected works in 55 volumes. Moscow: Politizdat. 1962b; 36:316-7 [in Russian].

20. Dekrety Sovetskoy vlasti [The Decrees of the Soviet Government]. March 17-July 10, 1918. Moscow: GIPL. 1959; 2:686 [in Russian].

21. Dekrety Sovetskoy vlasti [The Decrees of the Soviet Government. July 11-November 9, 1918. Moscow: IPL. 1964; 3:664 [in Russian].

22. Prishvin MM. V chernykh ochkah. Iz dnevnika (Rannee utro. 1918. No. 23. 17 fevralya). [Wearing black glasses. From the diary (Early morning. 1918. No. 23. February 17)]. In Prishvin MM Tsvet i Krest [Color and Cross]. Saint Petersburg: Rostok. 2004; 173-4. [in Russian].

23. Lenin VI. Proekt Programmy RKP(b) [Draft Program of the $\mathrm{RCP}(\mathrm{B})$. Collected works in 55 volumes. Moscow: Politizdat. 1963b; 38:81-124. [in Russian]. 